\title{
On Misunderstanding Heraclitus: the Justice of Organisation Structure
}

\author{
David Shaw ${ }^{1}$
}

Published online: 3 July 2018

(C) The Author(s) 2018

\begin{abstract}
Writers on organisational change often refer to the cosmology of Heraclitus in their work. Some use these references to support arguments for the constancy and universality of organisational change and the consignment to history of organisational continuity and stability. These writers misunderstand the scope of what Heraclitus said. Other writers focus exclusively on the idea that originated with Heraclitus that the universe is composed of processes and not of things. This idea, which has been particularly associated with Heraclitus's thought from the time of Plato, does indeed provide a rich source of insights into organisational analysis, not least the current trends towards giving proper attention to processual studies of organisational change. Yet there is some uncertainty as to whether Heraclitus actually said that the universe was composed exclusively of processes rather than things, and even if that was what he thought, he intended his ideas on flux to be understood not in isolation but in the context of other aspects of his cosmology. Writers on organisational change seldom make reference to this wider context. Heraclitus was a rational but also a religious thinker. A central element in his thought was the notion of divine Justice, which to a Greek of his era meant the order of the universe. Remote as his Olympian theology may seem today, it sets a crucial and entirely rational context for understanding his ideas about flux. It means that ideas about continuity and stability were quite as important in Heraclitus's cosmology as his more commonly quoted ideas about change. This paper sets out an overview of Heraclitus's philosophy, insofar as it appears to have potential relevance to organisational analysis, and discusses how far it supports or contradicts the ideas that organisational change scholars have drawn from it.
\end{abstract}

Keywords Heraclitus $\cdot$ Organisational change $\cdot$ Flux $\cdot$ Organisation structure $\cdot$ Dualities

David Shaw

1 London, UK 


\section{Introduction}

Heraclitus's fame from early antiquity has led past generations to use his authority to support a variety of claims, for example as to both the wisdom of Zeno and the coming of the Last Judgement (Barnes 1979). In our own generation, organisational change scholars have paid particular attention to the assertion that Plato attributes to Heraclitus that 'all things are in process and nothing stays still' (Kirk et al. 1983, p.195). They have used this assertion that everything is in flux as a source of authority for the need to redress the neglect of processes in the literature on organisational change management (Chia 1999). They often also quote Heraclitus's observations about flux as ancient authority for more general claims as to the overall prevalence of organisational change; as Sturdy and Grey (2003, p. 655) observe, 'just as strategy writers invoke Clausewitz or Sun-Tzu, the [Organisational Change Management] favourite is Heraclitus'. The metaphysical doctrine that Popper (1958-59) among other scholars attributes to Heraclitus, that the universe consists entirely of processes rather than of things, has been an important contribution to this line of thinking. While the case for paying closer attention to the processes whereby organisational change comes about has been well made (Pettigrew 2012), many organisational change scholars appear to have misunderstood Heraclitus. This misunderstanding is manifested in three main ways.

First, most organisational change scholars display excessive confidence in their interpretation of what Heraclitus said about flux, despite the presence of radically different interpretations among scholars of pre-Socratic philosophy (Popper 1958-59; Kirk 1960). Second, some organisational change scholars draw upon what Heraclitus said about flux to justify claims that organisational change is constant, and even that organisational continuity and stability is a mirage, when the most that can reasonably be inferred from Heraclitus's ideas about flux is that organisations are constituted of constantly changing micro-processes, which are quite consistent with the possibility of organisational continuity and stability (Tsoukas and Chia 2002). Third, organisational change scholars typically focus on what Heraclitus said about flux, but ignore other elements of his cosmology, in the absence of which his thinking about flux cannot properly be understood. These other elements of Heraclitus's cosmology are, first, his belief that the universe is governed by Justice (dike), that is, that the universe is ordered in accordance with rational, divine laws that are capable of being understood by insightful people and, second, that Justice is embodied in perpetual strife (eris) between opposites, which is reflected in Heraclitus's doctrine of the unity of opposites (Kirk et al. 1983; Lloyd-Jones 1983). This paper provides an overview of Heraclitus's thinking on these three elements of his cosmology - flux, Justice, and the unity of opposites - in the light of the available literature. It then discusses what insights can reasonably be drawn from his philosophy, and how far they are consistent with contemporary writing on organisational change.

Analysis of the thought of Heraclitus is complex at more than one level. Heraclitus was a citizen of Ephesus writing at the end of the sixth century BC. Kahn (1979) points out that the original text of the work of every philosopher before Plato, including Heraclitus, has been lost. Only fragments of Heraclitus's work that have been quoted by later writers have survived. There are therefore substantial problems in isolating what Heraclitus actually said from what later writers have attributed to him under the influence of their own particular purposes and convictions (Cherniss 1951). Moreover, Heraclitus was recognised, even in antiquity, as an obscure writer (Kirk et al. 1983), his style of expression was poetic and prophetic (Cherniss 1951; Emlyn-Jones 1976; Kahn 1979), and even when the words that he actually wrote have been clarified, problems remain in understanding what he meant by them. Despite the 
challenges, the effort to discover such insights about organisational change as we can from Heraclitus is worthwhile. As Platts and Harris (2011) argue, Heraclitus's contribution at the dawn of western philosophy is the origin of a key theme in how we think about the nature of reality, which has substantial implications for the ways in which we think and speak about organisations and organising. The frequent recourse of writers on organisational change to the authority and inspiration of Heraclitus argues for critical examination of their use of Heraclitus's thinking.

\section{Flux}

Plato's quotation of Heraclitus, 'all things are in process and nothing stays still' (Kirk et al. 1983, p.195), has been widely accepted as evidence that Heraclitus believed that the universe consisted of processes and not of things. Popper (1958-59), relying on his judgement as to what could constitute a cohesive philosophical position for Heraclitus to hold, accepts this as an accurate representation of what Heraclitus thought. Similarly Russell (1967) and Barnes (1979) accept that Heraclitus believed that everything was in flux. Heraclitus's view that the basic element that constituted the universe was fire, that is, a phenomenon that consists wholly of change, lends support to this interpretation (Cherniss 1951). Kirk (1960), however, arguing from textual criticism of the surviving fragments of Heraclitus's work, sees Popper's interpretation as an extreme one, and indeed questions the authenticity of what Plato wrote as a quotation of what Heraclitus actually said. Plato may well not have been attempting to present an accurate representation of the thought of Heraclitus, but rather may have been caricaturing what Heraclitus said for his own purposes (Colvin 2007; Kirk et al. 1983).

Plato's quotation could have been based on another assertion, which may have a better claim to be accepted as Heraclitus's actual words, that is, 'Upon those that step into the same rivers different and different waters flow' (Kirk et al. 1983, p.195). Heraclitus makes the point here that although a river may look like a stable object, anyone stepping into it will feel the flows of water that constitute it, and will thereby appreciate that its apparent stability depends on the regularity of those flows. Barnes (1979) draws attention to another fragment of Heraclitus that makes a comparable point. It is about a barley drink that has to be stirred in order for it to be enjoyed, and which separates into its component parts of barley, honey and wine in the absence of movement, thereby ceasing to be the drink that it is intended to be. According to Kirk (1960), although Heraclitus clearly saw some apparently stable things, such as rivers, as actually consisting of constant processes of change, he did not suggest that absolutely everything, for example a rock or a bronze cauldron, was undergoing continuous change. Kirk et al. (1983) argue that, for Heraclitus, processes of change must be observable through the senses, even though they might not at first sight be obvious, just as the flows of water in a river can be sensed by anyone stepping into it, and that he would not have accepted a claim that something was changing if that change were completely imperceptible even to the astute and thoughtful observer. It is sufficiently clear, however, that Heraclitus believed that at least in some cases what may at first sight appear to be stable objects are in fact processes, and at the same time it may be that he also believed that some other such objects are in fact exactly what they appear to be.

While the river fragment emphasises processes of change within the river, it is arguable that Heraclitus attached equal importance to the concept that there are measures that regulate the flows of water in the river, thereby maintaining its character (Kirk 1951). Other fragments of 
Heraclitus's work discuss divine Justice, that is, the laws that order the universe, which include measures that regulate its processes, such as the measures that control the flows of water in a river. Heraclitus's concept of Justice is discussed in the next section.

\section{Justice}

Heraclitus said that the 'sun will not overstep his measures; otherwise the Erinyes, ministers of Justice, will find him out' (Kirk et al. 1983, p. 201). From the earliest times, the Greeks believed that the universe was governed by Justice, by which they meant that it was ordered in accordance with divine laws, and that the Erinyes were the guardians of Justice (Lloyd-Jones 1983). Thus we can be assured that the sun will rise each morning, and set each evening, because the Justice whereby the universe is ordered has set measures that the sun cannot transgress. Heraclitus was a rational but also a religious thinker, who shared the religious outlook that is reflected in the Homeric poems (Adomenas 1999; Lloyd-Jones 1983; Vlastos 1952). Lloyd-Jones (1983) compares this quotation from Heraclitus with the passage in Homer's Iliad (1999, p.365) that describes how, when Achilles had urged his horses to bring him home safe from battle, one of the horses spoke to him in reply, foretelling Achilles's eventual death, and how 'when he had thus spoken the Erinyes checked his voice'. It is against Justice, the divine order of the universe, for horses to speak, and for that reason the Erinyes put a stop to it (Dodds 1973; Lloyd-Jones 1983). The idea that Justice governed the world underlay Heraclitus's thinking, but he believed that the nature of this Justice was perceptible only to those with special insight; he observed that 'to god all things are beautiful and good and just, but men have supposed some things to be unjust, others just' (Kirk et al. 1983, p. 191).

The moral implications of Justice in ancient Greek thinking flow from its meaning as the order of the universe, in that Justice sets clear boundaries that human beings must not transgress, especially as to their relationship to the gods. For example, Lloyd-Jones (1983) draws attention to the seventh Isthmian Ode of the fifth century poet Pindar (1947), which describes the fate of Bellerophon, who had to be thrown down to earth when, a mortal man, he tried to overstep Justice by flying up to heaven on the back of his winged horse, Pegasus. In another fragment, Heraclitus says that 'insolence is more to be extinguished than a conflagration' (Kirk et al. 1983, p. 211); the word 'insolence' (hybris) in this passage, which refers to the arrogance of people who transgress the limits set for them by the gods, leading inevitably to their destruction, means the opposite of Justice (Lloyd-Jones 1983).

There is no doubt that, irrespective of whether Heraclitus saw the universe as constituted wholly of processes rather than of things, he believed that the universe was ordered in accordance with measures determined by Justice. Thus, while Heraclitus's notion that much or even the whole of the universe consisted of processes might be suggestive of change, the regulation of the universe in accordance with the order set by Justice might rather suggest continuity and stability. A novel feature of Heraclitus's thinking is his association of Justice with strife; he writes that 'it is necessary to know that war is common and [Justice] is strife and that all things happen by strife and necessity' (Kirk et al. 1983, p. 193). ${ }^{1}$ Lloyd-Jones (1983) suggests that, in Heraclitus's mind, Justice is maintained by conflict between opposites. Heraclitus's doctrine of the unity of opposites is discussed in the following section.

\footnotetext{
${ }^{1}$ Kirk et al. (1983) render the Greek word dike as 'right' in their translation of this passage, although elsewhere they translate it as 'Justice'. This same translation of 'Justice' is restored here so as to clarify the argument.
} 


\section{Unity of Opposites}

One of the most striking assertions in Heraclitus's work is that of the unity of opposites, for example he writes that 'God is day night, winter summer, war peace, satiety hunger; he undergoes alteration the way that fire, when it is mixed with spices, is named according to the scent of each of them' (Kirk et al. 1983, p. 190). He wrote that people 'do not apprehend how being at variance it agrees with itself: there is a back-stretched connection, as in the bow and the lyre' (Kirk et al. 1983, p. 192). This theme was associated in his writing with the notion of measures (Kirk 1957); the tension between opposites has to be balanced in accordance with measures in order for the bow and the lyre to perform their functions, just as the regulation of the flows of water in a river in accordance with measures enable the river to maintain its apparent stability.

Heraclitus sets out various ways in which opposites may be unified. Opposite effects may be produced on different objects by the same thing, for example drinking sea water benefits fishes but harms men; opposite points of view may be produced by the same thing, for example the way up is the way down; unification of opposites is necessary to give meaning to some concepts, for example disease cannot be understood other than by reference to health; and some opposites are unified by the inevitable succession of the one by the other, for example youth and old age, and life and death (Kirk et al. 1983).

A key question here is whether Heraclitus believed literally that opposites were identical, or intended something less specific than that. Aristotle thought that Heraclitus believed literally in the identity of opposites, and that he was therefore violating the law of contradiction (EmlynJones 1976; Kirk et al. 1983). Barnes (1979) argues that Heraclitus did indeed intend to make the fallacious assertion that opposites are identical, because Heraclitus appears to have believed that he was asserting a striking, paradoxical truth, not the banal claim that there are cycles wherein, for example, night follows day, or death life. Kirk et al. (1983, p. 186) suggest, however, that when Heraclitus asserted the identity of opposites, what he meant was that they are 'not essentially distinct'. One of the fragments appears to support such a reading: 'And as the same thing there exists in us living and dead and the waking and the sleeping and young and old; for these things having changed round are those, and those having change round are these' (Kirk et al. 1983, p. 189). Emlyn-Jones (1976) argues, however, that the explanatory clause at the end of this fragment, which indicates that opposites simply form part of a cycle in which the one inevitably follows from the other, may have been added by a later writer, on the grounds that this fragment is unique in offering an explanation of the meaning of what Heraclitus asserted. It is clear that Heraclitus's doctrine of the unity of opposites either is fallacious, or else is too limited in intent and too imprecise in expression, to be regarded as a serious proposition about the nature of the universe. Nevertheless, the notion that tensions between opposite forces have to be managed, for example for the sake of the usefulness of a bow or a lyre, or indeed the maintenance of a sustainable demography as between young and old people, is applicable in a range of settings, including organisational change management.

In the following sections the paper discusses the linkages between the three elements of Heraclitus's thinking that are discussed above and contemporary writing on organisational change management. First, it discusses the linkages between Heraclitus's notion of flux and the role of processual analysis in writing on organisational change. Second, it discusses the linkages between Heraclitus's notion of Justice and the role of organisation structure in setting limits to managerial action and facilitating continuity and stability. Third, it discusses the linkages between Heraclitus's doctrine of the unity of opposites and contemporary writing on the role of dualities or polarities in organisational change. 


\section{Organisational Flux}

A number of writers on organisational change have drawn upon Heraclitus's references to flux in arguing for more attention to be paid to processual analysis of organisational change (Chia 1999; Langley et al. 2013; Van de Ven and Poole 2005). Earlier writing on organisational change has been criticised for subordinating discussion of change processes to discussion of stable structural and systemic organisational states to which those processes of change lead, which is well represented in Lewin's much-quoted 'unfreezing, changing, refreezing' model of organisational change (Chia 1999). Pettigrew et al. (2001, p.698) argue for the study of 'changing', as opposed to that of 'change', and in particular the need to study long-term processes of changing within the particular contexts in which they are embedded. Developing this line of thought, Van de Ven and Poole (2005) advocate substituting the verb, 'organising', for the noun, 'organisation', to reflect the perspective that continuing processes of organising are what constitute our institutions. Whittington and Melin (2003) argue that today's everfaster pace of change, firms' reliance on superior processes of organising and strategising for competing with their rivals, and the roles of processes for generating and applying new knowledge, make it necessary for dynamic thinking about organising to supplant traditional, Chandlerian thinking that focuses on the organisation structures to which processes of change lead to the neglect of analysis of those processes themselves. This new line of thought accords with the work of Pettigrew (2012), a strong advocate of processual organisational research and critic of scholarship that neglects the processes and contexts of change.

The view that processes rather than things constitute organisations is quite consistent with the possibility of organisational continuity and stability. Tsoukas and Chia (2002, p. 567) draw upon a reference to Heraclitus in advocating the view that change is 'the normal condition of organisational life'. They emphasise, however, that the existence of change in organisations does not 'mean that organisations constantly change' (Tsoukas and Chia 2002, p. 580). These writers illustrate their point with the analogy of the acrobat, whose apparent stability is dependent on the movements that are required to maintain that stability. The view that an organisation may be constituted of constantly changing micro-processes, while still maintaining its continuity and stability, is consistent with Heraclitus's identification of a river as being constituted of constantly changing flows of water. The view that organisations are constantly changing is far less consistent with what Heraclitus wrote.

Some pre-Socratic philosophy scholars argue that Heraclitus believed that some elements of the universe, such as rivers, consisted of processes rather than things, but that other elements, such as rocks and bronze cauldrons, were the unchanging things that they appeared to the senses to be (Kirk 1960). If correct, this interpretation might suggest that while some enterprises can be understood only in the dynamic terms advocated by Whittington and Melin (2003), others are best understood in terms of the static organisational structures conceived by Chandler (1962). While Van de Ven and Poole (2005) draw upon the thinking of Heraclitus in developing processual approaches to the study of organisational change, they advocate treatment of approaches that focus on processes of organising as complementing those that focus rather on organisations as things, each facilitating different ways of understanding organisational change.

It may be concluded that Heraclitus's philosophy lends support to the view that organisations may, at least in some circumstances, be viewed as consisting of constantly changing micro-processes. His philosophy also encourages study of the processes and sequences of organisational change rather than only the apparently stable states to which those processes of 
change lead. At the same time, Heraclitus's philosophy cannot be said with certainty to be absolutely opposed to looking at organisations as things, nor can it be used to justify denial of the possibility of organisational continuity and stability. While Morgan (1986) reasonably draws upon Heraclitus as inspiration for his image of organisations as flux, he does not thereby rule out other contrasting but potentially complementary images of organisations, for example as machines. The viability of alternative perspectives on organisation, specifically the potentially stabilising effect of organisation structure, is discussed below.

\section{Organisation Structure}

By contrast with Heraclitus's writing on flux, references to what Heraclitus said about the Justice that sets limits to the processes of the universe are conspicuous by their absence from the organisational change literature. Indeed a predominant theme in this literature has been how new organising practices do away with the limits on action that traditional, hierarchical organisational forms have set. According to Kirk (1951), a key purpose of Heraclitus's river fragment is to draw attention to the measures that Justice sets to the flows of water on which the continued existence of the same river depended. If Heraclitus's ideas encourage analysis of organisations as the outcomes of changing processes, therefore, they should equally encourage their analysis from the perspective of the limits that their structures set on managerial action and change.

Tsoukas and Chia (2002, p. 570) observe that 'organisation is an attempt to order the intrinsic flux of human action, to channel it towards certain ends, to give it a particular shape, through generalising and institutionalising particular meanings and rules'. Organisation, and specifically organisation structure, is a means of setting limits to managerial action. Giving priority to the notion of organising processes as flux over that of organisation structure as a means of imposing order on that flux, risks succumbing to the 'bias for change' of which Sturdy and Grey (2003, p.660) complain. Cyert and March (1992, p.38) place particular emphasis on the role of organisation structure in setting limits to managerial action - 'if ... we consider the allocation of functions in much the same way we would normally consider the allocation of resources during budgeting ... when we define the limits of discretion, we constrain the individual or subgroup from acting outside those limits; but at the same time, we constrain any other members of the coalition from prohibiting action within those limits'.

A key theme in contemporary writing about organisational change is the claim that traditional, hierarchical organisation structures, of the type that might be seen as imposing order on the flux of organising processes and setting limits to them, are being replaced by flexible, networked organisational forms that do away with such limitations. Ashkenas et al. (1995, p.2) typify this theme with their notion of the 'boundaryless organisation', claiming that 'behaviour patterns that are highly conditioned by boundaries between levels, functions and other constructs will be replaced by patterns of free movement across those same boundaries'. Yet these claims, that hierarchical organisation structures are being done away with, have prompted strong responses 'in praise of hierarchy' (Jaques 1990; Koplowitz 2008), which draw attention to the contributions of hierarchical structures in making accountability and authority for decision-making clear, and of the separate managerial levels that they provide in matching the complexity of the work with the competency level needed to do it. The 'Innovative Forms of Organising' (INNFORM) research programme was undertaken by an international network of scholars to examine the claims that new organisational forms were 
replacing traditional hierarchical structures, focusing in particular on claims that organisations were moving towards increasing decentralisation of decision-making, delayering, increasing use of project teams, facilitation of increased horizontal interaction across structural boundaries through new ways of managing people and technology, and redefinition of external organisational boundaries, for example through outsourcing and strategic alliances (Fenton and Pettigrew 2000). Summarising conclusions from this research programme, Pettigrew and Massini (2003, pp. 31-32) observe that, although some of these new organising practices are indeed in evidence, they are 'supplementing not supplanting existing forms'. This suggests that while organisations are indeed becoming more flexible and less hierarchical, organisation structure continues to be a framework that sets limits to processes of change and facilitates organisational continuity and stability.

Like a river, an organisation is the setting for continuous flows of action and change, yet the organisation's structure guides those flows so that the identity of the organisation as a stable entity can be maintained. Of course, there will be times when the force of those flows will be so great as to overwhelm the structures that have been containing them, leading to organisational change rather than only change within the organisation. The order that organisation structure imposes on the organising processes through which it has itself been formed can be compared with Heraclitus's notion of the Justice that orders the universe. Heraclitus's universe might have consisted of the flux of ever-living fire, but it is ordered by rational laws that permit continuity and stability (Kirk 1951). The embodiment of this order in the unity of opposites is discussed in the following section.

\section{Dualities}

Heraclitus's notion of 'how being at variance it agrees with itself' (Kirk et al. 1983, p. 192) anticipates a range of ideas in modern organisation theory, in particular those relating to the management of dualities or polarities. Jing and Van de Ven (2016) draw upon Heraclitus's writing on flux, and his associated idea of the unity of opposites, to argue for an 'either/and' approach to organising, such as that reflected in dualities management. In particular these writers compare Heraclitus's doctrine of the unity of opposites, whereby for example successive replacement of one phenomenon by its opposite - as night replaces day, old age youth, and death life - maintains the balance of the universe, with contemporary perspectives that identify balancing apparently opposite forces as a key management task. Sutherland and Smith (2013, p.220) describe the idea of dualities in similar terms to Heraclitus's writing on the unity of opposites, for example they say that 'duality theory specifies that complementarities exist within contradiction and their synergistic co-existence ensures that the qualities of both dimensions ... are recognised and exploited'. Just as Heraclitus says that the sun may not 'overstep his measures' (Kirk et al. 1983, p. 201), so these writers argue that each polarity in a duality must be maintained at a 'minimal threshold' in order to secure the benefits from the tensions between the two polarities of the duality (Sutherland and Smith 2013, p.227). For Sutherland and Smith (2013, p.216), continuity and change constitute one of the key dualities, coexisting 'as dualities that sit side by side without compromising one another'.

Sánchez-Runde and Pettigrew (2003), in reviewing findings from the INNFORM research programme, identify numerous instances of dualities management in the organisations that they studied. These include managing hierarchies and networks, strengthening of upward accountability within management structures while facilitating increased horizontal 
communication, and centralising of strategy formation while decentralising operational activities. These observations indicate that managers are balancing new ways of organising that are suggestive of increasing flexibility and change with more traditional concerns with the maintenance of hierarchical control that are suggestive of continuity and stability. In language that seems to echo the words of Heraclitus, Sánchez-Runde and Pettigrew (2003, p. 245-246) say that dualities are 'opposing forces that need to be balanced because, even if they are seen as paradoxical or contradictory, in fact they are complementary', and that dualities management is not 'choosing between right and wrong, but potentially between right and right'.

Seo et al. (2004) identify a range of ways of managing dualities that are in some respects aligned with Heraclitus's ideas about the unity of opposites. One of these management approaches is separation, whereby managers might focus on one polarity at one time and the other at a different time, or might adopt one polarity at one organisational level and the other at a different organisational level. Just as day follows night, Sánchez-Runde and Pettigrew (2003) suggest that managers might first encourage individualism in order to overcome conformist thinking, but might later encourage collaborative working in order to overcome the uncooperativeness to which individualism might lead. Moreover, just as drinking sea water benefits fishes but harms men, Dunphy and Stace (1993) find that organisations often appear to adopt a directive change leadership style at a corporate level, but a consultative one at business unit level. Integration is another approach to managing dualities suggested by Seo et al. (2004), whereby the opposite polarities are balanced within considered limits, as in a bow or a lyre, with neither polarity being addressed in its entirety. Sánchez-Runde and Pettigrew (2003) identify circumstances, for example, in which the tensions between pressures for change exerted by senior management on their subordinates may need to be balanced with nurturing of energy for change among those subordinates.

For Heraclitus, the doctrine of the unity of opposites embodies the notion of Justice, or the order of the universe. It attempts to explain how, even where apparently stable entities are constituted of changing processes, order may yet be maintained. The findings of the INNFORM research programme provide empirical evidence of how dualities involving both traditional hierarchical structures and new, more networked ways of organising may be managed in ways that facilitate both continuity and change. The notions of flux, organisation structure, and dualities - all ideas that can be connected with the thought of Heraclitus provide useful, complementary perspectives on organisational analysis.

\section{Conclusion}

The cosmology of Heraclitus, despite its obscurities and difficulties of interpretation, provides a rich seam of thought that can enlighten contemporary organisational analysis. This is the origin of a tradition of metaphysical philosophy from the time of Plato to the present day that encourages a view of reality as processes rather than as things. Many organisational change scholars have drawn upon this theme, sometimes with explicit acknowledgement of Heraclitus's contribution, to develop a view of organisational change that addresses not only the organisational forms to which change leads, and the contexts in which those developments and transformations occur, but also the sequences and processes of action through which the change emerges (Van de Ven and Poole 2005). Some scholars have recognised, in line with Heraclitus's thought, that continuously changing processes within an organisation do not necessarily lead to organisational change, because balance among changing processes may 
promote continuity and stability rather than change (Tsoukas and Chia 2002). Heraclitus's doctrine of the unity of opposites anticipates, and has on occasion been acknowledged as a source of, the idea of dualities or polarities in organisations, and the need for managers to balance apparently opposed forces. Much of Heraclitus's work endorses, and is acknowledged by organisational change scholars to have contributed towards, contemporary thinking on organisations.

As Sturdy and Grey (2003, p. 660) say, however, writers on organisational change too often use the authority of Heraclitus to justify a 'bias for change'. From the time of Plato, particular attention has been paid to Heraclitus's remarks about flux. Yet, there is some uncertainty as to whether Heraclitus ever said that the universe is composed exclusively of processes rather than of things. It may well be that this this interpretation of his work is correct, but it is beyond doubt that he did not hold that view in isolation. He associated it with other ideas about the order of the universe that set measures to those processes, and about the unity of opposites whereby tensions between opposing forces were kept in balance. These ideas argue for balanced adoption of a range of different but complementary perspectives in studying organisations, rather than an exclusive or near-exclusive focus on our enterprises and institutions as arenas for constant and all-embracing processes of organisational change. As a writer who shared much of the religious outlook of Homer, Hesiod and Aeschylus (Lloyd-Jones 1983), it is perverse to pay attention to Heraclitus's ideas about change while ignoring his belief in Justice, the divine laws that ordered his universe, and in the forces of continuity and stability.

\section{Compliance with Ethical Standards}

Conflict of Interest The author states that there is no conflict of interest.

Open Access This article is distributed under the terms of the Creative Commons Attribution 4.0 International License (http://creativecommons.org/licenses/by/4.0/), which permits unrestricted use, distribution, and reproduction in any medium, provided you give appropriate credit to the original author(s) and the source, provide a link to the Creative Commons license, and indicate if changes were made.

\section{References}

Adomenas, M. 1999. Heraclitus on religion. Phronesis 44 (2): 87-113.

Ashkenas, R., D. Ulrich, T. Jick, and S. Kerr. 1995. The Boundaryless organization: Breaking the chains of Organisational structure. San Francisco: Jossey-Bass.

Barnes, J. 1979. The pre-Socratic philosophers. New York: Routledge \& Kegan Paul Ltd..

Chandler, A.D. 1962. Strategy and structure: Chapters in the history of the American industrial Enterprise. Cambridge: The MIT Press.

Cherniss, H. 1951. The characteristics and effects of pre-Socratic philosophy. Journal of the History of Ideas 12 (3): 319-345.

Chia, R. 1999. A 'Rhizomic' model of Organisational change and transformation: Perspective from a metaphysics of change. British Journal of Management 10: 209-227.

Colvin, M. 2007. Heraclitean flux and unity of opposites in Plato's 'Theaetetus' and 'Cratylus'. The Classical Quarterly, New Series 57 (2): 759-769.

Cyert, R.M., and J.G. March. 1992. A Behavioural theory of the firm (second edition). New Jersey: Blackwell Publishing.

Dodds, E.R. 1973. The Greeks and the irrational. Berkeley: University of California Press.

Dunphy, D., and D. Stace. 1993. The strategic Management of Corporate Change. Human Relations 45 (8): $905-920$. 
Emlyn-Jones, C.J. 1976. Heraclitus and the Unity of opposites. Phronesis 21 (2): 89-114.

Fenton, E., and A.M. Pettigrew. 2000. Theoretical perspectives on new forms of Organising. In The innovating organisation, ed. A.M. Pettigrew and E. Fenton, 1-46. London: Sage.

Homer. 1999. The Iliad Books 13-24 (Second Edition), Translated by A.T. Murray, Revised by W.F. Wyatt. Cambridge: Harvard University Press.

Jaques, E. 1990. In praise of hierarchy. Harvard Business Review 68 (1): 127-133.

Jing, R., and A.H. Van de Ven. 2016. Being versus becoming ontology of paradox management. Cross Cultural and Strategic Management 23 (4): 558-562.

Kahn, C.H. 1979. The art and thought of Heraclitus: An edition of the fragments with translation and commentary. Cambridge: University Press.

Kirk, G.S. 1951. Natural change in Heraclitus. Mind 60 (237): 35-42.

Kirk, G.S. 1957. Men and opposites in Heraclitus. Museum Helveticum 14 (3): 155-163.

Kirk, G.S. 1960. Popper on science and the pre-Socratics. Mind 69 (275): 318-339.

Kirk, G.S., J.E. Raven, and M. Schofield. 1983. The pre-Socratic philosophers (second edition). Cambridge: University Press.

Koplowitz, H. 2008. In praise of top-down decision making in managerial hierarchies. World Futures 64: 513-523.

Langley, A., C. Smallman, H. Tsoukas, and A.H. Van de Ven. 2013. Process studies of change in organisation and management: Unveiling temporality, activity and flow. Academic of Management Journal 56 (1): 1-13.

Lloyd-Jones, H. 1983. The justice of Zeus (second edition). Berkeley: University of California Press.

Morgan, G. 1986. Images of organisation. Beverley Hills: Sage Publications.

Pettigrew, A.M. 2012. Context and action in the transformation of the firm: A reprise. Journal of Management Studies 49 (7): 1304-1328.

Pettigrew, A.M., and S. Massini. 2003. Innovative forms of Organising: Trends in Europe, Japan and the USA in the 1990s. In Innovative forms of Organising, ed. A.M. Pettigrew, R. Whittington, L. Melin, C. SánchezRunde, F.A.J. Van Den Bosch, W. Ruigrok, and T. Numagami, 1-32. London: Sage.

Pettigrew, A.M., R.W. Woodman, and K.S. Cameron. 2001. Studying organisational change and development: Challenges for future research. Academy of Management Journal 44 (4): 697-713.

Pindar. 1947. Pindari Carmina cum Fragmentis (second edition). Oxford: University Press.

Platts, J., and H. Harris. 2011. The place of philosophy in management. Philosophy of Management 10 (2): 19-39.

Popper, K.R. 1958-1959. Back to the pre-Socratics: The presidential address. Proceedings of the Aristotelian Society, New Series 59: 1-24.

Russell, B. 1967. A history of western philosophy. New York: Simon and Schuster.

Sánchez-Runde, C.J., and A.M. Pettigrew. 2003. Managing Dualities. In Innovative forms of Organising, ed. A.M. Pettigrew, R. Whittington, L. Melin, C. Sánchez-Runde, F.A.J. Van Den Bosch, W. Ruigrok, and T. Numagami, 243-250. London: Sage.

Seo, M.-G., L.L. Putnam, and J.M. Bartunek. 2004. Dualities and tensions of planned Organisational change. In Handbook of organisational change and innovation, ed. M.S. Poole and A.H. Van de Ven, 73-106. Oxford: University Press.

Sturdy, A., and C. Grey. 2003. Beneath and beyond Organisational change management: Exploring alternatives. Organisation 10 (4): 651-662.

Sutherland, F., and A.C.T. Smith. 2013. Leadership for the age of sustainability: A dualities approach to organisational change. In Organisational change, leadership and ethics: Leading organisations towards sustainability, ed. R.T. By and B. Burnes, 216-239. London: Routledge.

Tsoukas, H., and R. Chia. 2002. On Organisational becoming: Rethinking Organisational change. Organisation Science 13 (5): 567-582.

Van de Ven, A.H., and M.S. Poole. 2005. Alternative approaches for studying Organisational change. Organisation Studies 26 (9): 1377-1404.

Vlastos, G. 1952. Theology and philosophy in early Greek thought. The Philosophical Quarterly 2 (7): 97-123.

Whittington, R., and L. Melin. 2003. The challenge of Organising/Strategising. In Innovative forms of organising, ed. A.M. Pettigrew, R. Whittington, L. Melin, C. Sánchez-Runde, F.A.J. Van Den Bosch, W. Ruigrok, and T. Numagami, 35-48. London: Sage.

David Shaw is a Visiting Lecturer in the Human Resources and Organisational Behaviour Department of the University of Greenwich Business School. Before joining the University of Greenwich he was a management consultant for over 20 years, specialising in the management of organisational change. David was awarded a Doctorate in Business Administration by Manchester Business School for research into organisational change. He studied Classics at New College, Oxford before embarking on a career in business administration. 